\title{
Alma, Corpo e a Antiga Civilização Grega: As Primeiras Observações do Funcionamento Cerebral e das Atividades Mentais
}

\author{
Soul, Body and the Ancient Greek Civilization: The First Observations \\ of Brain Functioning and Mental Activities
}

\author{
Fabiano S. Castro*, a \& J. Landeira-Fernandez ${ }^{a, b}$ \\ ${ }^{a}$ Pontificia Universidade Católica do Rio de Janeiro, Rio de Janeiro, Brasil \\ $\&{ }^{b}$ Universidade Estácio de Sá, Rio de Janeiro, Brasil
}

\begin{abstract}
Resumo
Muitos dos conceitos existentes na neurociência moderna possuem suas origens nas especulações elaboradas pelos antigos filósofos e médicos gregos. Questões centrais sobre a fonte dos pensamentos humanos, o mecanismo da atividade cognitiva, e a natureza das emoções, percepção e movimento voluntário, por exemplo, foram levantadas pelos pensadores gregos. É a partir desta civilização que surgem as observações mais sistemáticas sobre a estrutura e o funcionamento do corpo, da mente e a relação entre estas duas entidades. Assim, o presente trabalho pretende observar as principais tentativas iniciais gregas em vincular estruturas do corpo (tais como o cérebro ou o coração) e atividades mentais, ao longo das diversas especulações gregas sobre a natureza, a filosofia, a psicologia e a medicina.
\end{abstract}

Palavras-chaves: Relação Mente-Corpo; Relação Mente-Cérebro; Grécia Antiga; História da Neurociência.

\begin{abstract}
Many of the existing concepts in modern neuroscience have their origins in the speculations made by ancient Greek philosophers and physicians. Core questions about the source of human thought, the mechanism of cognitive activity as well as the nature of emotions, perceptions and voluntary movements, for example, were raised by Greek thinkers. It is from this civilization that arise more systematic observations on the structure and functioning of body, mind and relationship between these two entities. The present paper intends to adhere to the first Greek attempts to link structures of the body (such as the brain or the heart) and mental activities regarding various Greek speculations about the nature, philosophy, psychology and medicine.

Keywords: Mind-Body Relationship; Mind-Brain Relationship; Ancient Greece; History of Neuroscience.
\end{abstract}

O grande avanço das neurociências na atualidade vem permitindo compreender cada vez mais os diferentes circuitos neurais associados às diferentes funções mentais (ver, por exemplo, Landeira-Fernandez \& Silva, 2007). Contudo, questões fundamentais relacionadas à natureza da mente humana ainda permanecem em aberto (P. M. Churchland, 2004; P. S. Churchland, 1996). Essas questões, fundamentais nas ciências da mente contemporâneas, estiveram também presentes nas primeiras organizações antigas humanas. Desde os primórdios da humanidade e em diferentes civilizações antigas, como Egito, Mesopotâmia, Índia e China, observa-se a construção de diversas perspectivas acerca da relação mente-corpo, con-

\footnotetext{
* Endereço para correspondência: Pontifícia Universidade Católica do Rio de Janeiro, Centro de Teologia e Ciências Humanas, Departamento de Psicologia, Rua Marques de São Vicente, 225, Gávea, Rio de Janeiro, RJ, Brasil, CEP 22453-900. E-mail: fabianoscastro@gmail.com e landeira@puc-rio.br
}

temporâneas entre si e que refletem uma preocupação fundamental em compreender como ocorre a relação entre nossos corpos e os fenômenos mentais (Castro \& Landeira-Fernandez, 2010; Gomes, 2004).

E de maneira similar às civilizações supracitadas, notase também na Grécia antiga a existência de tais preocupações. Na verdade, nenhuma outra cultura antiga deixou marcas ainda tão presentes como a civilização grega. Pode-se afirmar que a base de todo pensamento ocidental moderno encontra suas origens nesta civilização (Burnet, 1994; Snell, 2001; Vernant, 1998). Indo além, diversos conceitos encontrados na neurociência moderna possuem alguma origem nas diferentes especulações elaboradas pelos antigos filósofos e médicos gregos (Crivellato \& Ribatti, 2007). As propostas feitas por esses pensadores a respeito de questões centrais - relacionadas com a fonte do pensamento humano, o mecanismo da atividade cognitiva e a natureza das emoções, percepção e movimento voluntário - ainda nos fascinam e con- 
tribuem pela originalidade e pela riqueza de suas implicações, marcando de maneira fundamental o pensamento científico e filosófico da Idade Moderna (Finger, 1994; Frias, 2004; Ivanovic-Zuvic, 2004; Quin, 1992).

Desse modo, é seguro afirmar que a cultura grega antiga serve como um marco na fundação do pensamento ocidental. É a partir desta civilização que surgem observações mais sistemáticas sobre estrutura e funcionamento do corpo, da mente e a relação entre estas duas entidades. Assim, o presente trabalho tem como objetivo apresentar as principais tentativas no pensamento grego em vincular estruturas do corpo (tais como o cérebro ou o coração) às atividades mentais (tais como as emoções, o pensamento e a memória), ao longo das inúmeras considerações gregas sobre natureza, filosofia e medicina.

\section{O Corpo Homérico}

A visão de corpo e mente encontrada na Grécia Antiga sofreu grande influência do pensamento filosófico emergente no século $\mathrm{V}$ a.C. Entretanto, em um período anterior - entre 1200 e 800 a.C. - os antigos gregos já apresentavam algumas considerações acerca do assunto. É a partir das obras de Homero que temos acesso ao pensamento grego deste período (Reale, 2002).

Homero é considerado o primeiro grande poeta grego sobre o qual temos conhecimento. Viveu na Jônia e são a ele atribuídas as obras Ilíada e Odisséia, consideradas compostas na segunda metade do século VIII a.C. Estas duas obras narram, em versos, as batalhas de Tróia e seus eventos associados. Juntas, constituem os mais antigos documentos literários gregos (e ocidentais) existentes hoje, datados entre o final do século VIII a.C. e início do século VII a.C. Contudo, ainda se discute a real existência de Homero e se as duas obras foram realmente compostas pela mesma pessoa (Demetrios, 2001).

Além disso, as duas obras servem como principal fonte de informação acerca dos hábitos sociais, práticas políticas, costumes religiosos e crenças dos antigos gregos, entre o período da suposta Guerra de Tróia (por volta de 1200 a.C.) e o tempo de Homero, que supostamente viveu a cerca de quatro séculos após as batalhas (Burnet, 1994; Snell, 2001). É a partir de suas narrações que se conhece sobre a estrutura social e cultural da época, além de nos apresentar indícios de como era vista a relação entre o corpo e a alma (ou mente) e como eram definidos os conceitos de saúde e enfermidade.

$\mathrm{Na}$ Ilíada, observam-se diversas alusões a inúmeros ferimentos (cerca de 141 a 147), localizados nas regiões da cabeça, pescoço, peito, abdômen e membros; ferimentos estes por vezes acompanhados de fraturas ou mesmo de esmagamento de ossos, causados por lanças, punhais, flechas ou pedras. Além disso, variam desde aqueles capazes de gerar morte instantânea (como uma flecha que penetra por trás do pescoço) até aqueles ocorridos devido a uma comoção cerebral, como uma pan- cada à altura do capacete (Crivellato \& Ribatti, 2007; Demetrios, 2001; Porto, Moreira, \& Simão, 2001). Obviamente, não havia uma preocupação em se fazer uma descrição detalhada de questões anatômicas e funcionais das diversas partes do corpo.

A anatomia presente nos textos homéricos é extremamente semelhante àquela encontrada em outras civilizações antigas e deriva principalmente da observação ou da realização de sacrifícios (Demetrios, 2001). Embora os principais órgãos fossem conhecidos, os primeiros gregos tinham pouco conhecimento funcional dessas partes, exceto algumas características mais elementares (Crivellato \& Ribatti, 2007; Demetrios, 2001). Dessa forma, o conhecimento anatômico e fisiológico desta época era extremamente limitado. Entretanto, observa-se que o guerreiro homérico sabia quais partes da anatomia humana do inimigo deveriam ser atacadas de maneira eficaz (Ivanovic-Zuvic, 2004; Porto et al., 2001).

A idéia de um corpo, tal como entendemos hoje, está ausente nos poemas épicos. Na Grécia Homérica, o corpo era visto como um aglomerado de membros, representados no ritmo dos seus movimentos, bem como na força de sua musculatura (Vernant, 1998). Dessa forma, em Homero, o corpo não é representado através de um termo unitário; pelo contrário, faz-se uso de uma multiplicidade de termos e representações para falar do corpo (Reale, 2002). Assim, o homem homérico empregava os termos guya ou gyia (se referindo aos membros do corpo em movimento) e melea (se referindo aos membros dotados de força muscular). Era também empregada a palavra demas para designar a estrutura, o tamanho e a semelhança (Snell, 2001).

Segundo Snell (2001), os gregos homéricos não tinham ainda desenvolvido uma concepção unitária da vida psíquica. Para esse autor, a ausência de uma palavra nos textos referente a esta unidade psíquica pode ser considerada como uma evidência da inexistência desse conceito. Assim, não há termos em Homero para estruturas da atividade mental comparáveis às palavras "alma" ou "mente", por exemplo.

Entretanto, Reale (2002) apresenta uma série de termos utilizados por Homero para se referir à vida mental do homem antigo. O primeiro termo destacado pelo autor é "coração" (expresso pelas palavras kradie, ker e etor, basicamente sinônimos), que se referia não somente ao órgão físico, mas também aos sentimentos e afetos. Para o homem homérico, seria no "coração" onde os sentimentos se manifestariam, não havendo distinção entre o processo psíquico e o órgão físico em si.

Homero também fez uso do termo thymos, referindose ao estado de ânimo do sujeito. O termo ocorre centenas de vezes ao longo dos versos e se refere à esfera das emoções: seja associado ao órgão dos sentimentos; seja com o surgimento e função dos sentimentos; seja com os efeitos das emoções no comportamento do sujeito. Dessa forma, thymos é empregado em diversos sentidos. Consi- 
derada como a fonte das emoções, do ímpeto e do arrebatamento do coração valente, thymos seria o gerador do movimento e da ação, localizado na região do peito (Porto et al., 2001; Snell, 2001).

Além disso, Reale (2002) considera que o termo também representaria uma série de experiências mentais similares aos conceitos de "suposição", "intuição" ou "conhecimento imediato". Entretanto, aponta para o fato de que este "conhecimento" de thymos estaria sempre ligado a um estado afetivo. Por fim, thymos às vezes também pode ser compreendido como um conceito de "vida" em seu sentido amplo, pois estaria associado com a respiração (Reale, 2002).

Outro termo relacionado com a vida psíquica seria phren (ou phrenes, no plural). Localizado na região do diafragma, estaria associado ao intelecto e ao pensamento em ação. Segundo Reale (2002), phren pode ser tomado como "mente", pois se referia à relação entre determinado conhecimento e a ação decorrente do pensamento. Além disso, phren possuiria também um caráter ético, podendo ser interpretado como "juízo" ou "julgamento" em determinados trechos dos poemas épicos.

Entretanto, Homero utiliza o termo noos para se referir ao ato de pensar de maneira mais abstrata. Seria noos aquilo que permitiria ao indivíduo adquirir uma representação do mundo capaz de proporcionar idéias claras a respeito deste. Assim, associado com a formação de imagens e das idéias puras, noos se refere à razão, ao discernimento e à inteligência. Tal como phren, noos também estaria localizada no peito, mas sem nenhuma associação com alguma estrutura específica (Crivellato \& Ribatti, 2007; Ivanovic-Zuvic, 2004; Porto et al., 2001; Snell, 2001).

Reale (2002) também aponta para o termo psyché, que se referia ao "sopro da alma" e estaria associado com a respiração. No momento da morte, a psyché sairia pela boca, como um suspiro, ou através das feridas e abandonaria o corpo vagando pelas regiões sombrias do Hades como uma sombra inconsistente (Ivanovic-Zuvic, 2004; Porto et al., 2001; Snell, 2001). Entretanto, não há na obra homérica uma definição clara para psyché e nem uma descrição de seu papel enquanto o indivíduo estivesse vivo. Esta psyché apenas abandonaria o seu dono quando este morresse ou perdesse a consciência. Dessa forma, Homero utiliza o termo psyché sobretudo associado com o momento da morte do indivíduo (Reale, 2002).

Apesar disso tudo, não é feita uma distinção clara, em Homero, entre a estrutura dos órgãos da mente e a atividade ou função desses órgãos (Crivellato \& Ribatti, 2007). Assim, um termo pode se referir tanto a um órgão como ao ato em si associado com tal órgão. Segundo Snell (2001), o vocabulário homérico tende a ser mais concreto do que abstrato, refletindo a ausência de conceitos elaborados a respeito da relação entre a mente e o corpo, na cultura grega homérica.

\section{As Primeiras Considerações Filosóficas Sobre o Corpo e a Mente}

Pode-se dizer que a filosofia nasce na Grécia Antiga como uma cosmologia, na qual o objeto de reflexão é a própria natureza (phýsis), numa busca por explicações acerca do mundo natural e baseada essencialmente em causas naturais. É desta forma que os primeiros filósofos se preocuparam em observar os fenômenos de maneira ampla, numa tentativa de identificar o princípio ordenador da natureza (arkhé) e expressá-lo em uma linguagem racional (Barnes, 2003; Chauí, 2002; Marcondes, 2008).

A característica central da explicação dada pelos primeiros filósofos é o uso da noção de causalidade. Ao mesmo tempo, com o intuito de evitar a regressão ao infinito em busca da explicação causal, os primeiros filósofos postularam a existência de um elemento primordial o qual serviria de ponto de partida para todo o processo. O primeiro a formular essa noção foi Tales de Mileto (aproximadamente 585 a.C.), que afirmou ser a água o elemento primordial.

Considerado como o primeiro filósofo, Tales de Mileto inaugurou uma nova visão a qual toma o mundo como obediente a uma ordem e não governado pelo divino; os próprios princípios internos da natureza são suficientes para explicar sua estrutura (Barnes, 2003). Esta nova concepção de mundo provocou durante o século VI a.C. e grande parte do século seguinte uma crescente produção de teorias as quais substituíram o mito como explicação dos fenômenos da natureza (Burnet, 1994; Mondolfo, 1973; Snell, 2001; Vernant, 1998).

O estabelecimento de uma conexão causal entre os fenômenos naturais constitui a estrutura básica da explicação científica e, em grande parte, essas primeiras tentativas de se elaborar explicações acerca da natureza se configuram como o início de um pensamento científico (Snell, 2001). De fato, diversas áreas da ciência começaram, de alguma forma, através da exploração filosófica de algum de seus aspectos (Russell, 2002). Entretanto, nesse primeiro momento, não há ainda uma distinção clara entre uma ciência empírica e uma filosofia especulativa, não se estabelecendo fronteiras intelectuais entre os diferentes campos de saber (Barnes, 2003). Consequentemente, percebe-se uma sobreposição dos diferentes campos de conhecimento.

Dessa forma, essa filosofia da natureza influenciou diretamente a visão de organização e funcionamento do corpo humano. O homem é compreendido como parte da natureza universal e, portanto, sujeito aos mesmos princípios os quais regeriam os fenômenos físicos. Por exemplo, como aponta Frias (2004), as considerações feitas pelos filósofos pré-socráticos foram utilizadas pelos médicos do século V a.C. como base de suas observações a respeito da enfermidade, saúde e fisiologia humana.

É somente a partir dessa nova forma de se pensar que vemos uma organização e uma preocupação maior em se 
estabelecer, de forma racional e sistemática, um conhecimento a respeito da mente (ou alma), sua relação com o corpo e como esse corpo funciona. Com a filosofia nascente, ocorrem as primeiras tentativas de interpretar o fenômeno natural de maneira racional, possibilitando a exploração de diferentes aspectos biológicos e psicológicos. Estas explorações levaram ao desenvolvimento de hipóteses as quais procuravam responder às questões associadas à atividade cognitiva e à sua localização no corpo.

Anaxímenes (nascido em torno de 560 a.C.), da escola de Mileto, considerou que a fonte do pensamento humano seria o $a r$, elemento básico tanto do mundo físico quanto do psicológico. Segundo o depoimento de Plutarco (45 - 120 a.C.), Anaxímenes considerava que "nossas almas, sendo ar, nos mantêm unidos, e a respiração e o ar compreendem o mundo todo" (como citado em Barnes, 2003, p. 94; Kirk, Raven, \& Schofield, 1990). De forma parecida, Diógenes de Apolônia (499 - 428 a.C.) também atribuiu ao ar a capacidade de produzir pensamentos, sensações e vida. O intelecto se manifestaria quando o $a r$, misturado com o sangue, percorresse todo o corpo através das veias (Barnes, 2003; Kirk et al., 1990). Diógenes considerou que seria o cérebro a sede do intelecto. Quando o ar era respirado, este iria diretamente para o cérebro, deixando lá suas melhores partes (Crivellato \& Ribatti, 2007; French, 1978).

Entretanto, outros filósofos tentaram ser ainda mais específicos na localização dos processos cognitivos no corpo. Empédocles de Agrigento (495 - 435 a.C.), filósofo e médico, foi um deles. Considerava que a natureza era composta por quatro elementos primordiais: a água, o fogo, a terra e o ar. Havia ainda dois outros princípios cosmogônicos: a Amor e o Ódio. O Amor seria responsável em promover a união entre os elementos primordiais, enquanto o Ódio, a separação deles (Barnes, 2003). Como veremos mais a frente, esta proposta teve grande influência na visão médica sobre os conceitos de enfermidade e saúde. Além disso, Empédocles apresentou grande interesse na fisiologia referente aos fenômenos sensoriais, desenvolvendo idéias relevantes sobre o assunto, as quais algumas possuem certa proximidade com Diógenes de Apolônia (Barnes, 2003; Batista, 2003; Frias, 2004; Kirk et al., 1990).

Segundo Empédocles, a percepção aconteceria devido aos poros sensoriais serem capazes de captar as emanações dos quatro elementos primordiais feitas pelos objetos (Barnes, 2003). Sua teoria tem como base o fundamento da atração dos semelhantes. Por exemplo, durante a fase cósmica do Amor, as partículas do fogo presentes no objeto partiriam em direção aos olhos os quais também seriam permeados de partículas de fogo. Entretanto, a percepção visual só seria capaz de ocorrer devido à seleção dos poros do órgão visual, que permitiriam a entrada somente de partículas elementares similares àquelas presentes nos olhos, cujas dimensões não ultrapassem seus limites. Isso causaria tanto a sensação da luz e das cores, assim como a percepção da forma dos objetos (Barnes, 2003; Batista, 2003; Frias, 2004; Kirk et al., 1990). Esta proposta de Empédocles sobre as sensações influenciou diretamente o pensamento de Platão e teve grande impacto no pensamento relacionado à fisiologia sensorial, por séculos.

Além disso, assim como Diógenes, Empédocles considerou o sangue importante na produção dos pensamentos. Entretanto, discordou de Diógenes sobre a localização do intelecto no cérebro e apontou que esta seria produzida pelo sangue; mais especificamente, o sangue concentrado na região do coração (French, 1978). Para Empédocles, o pensamento dependeria da similaridade, como se pensar fosse o mesmo que perceber. É a partir da maneira pela qual reconheceríamos as coisas por seus semelhantes que a reunião de todas estas coisas nos permitiria pensar. Como apresentou Teofrasto $(372-282$ a.C.), em Sobre os Sentidos, "Eis a razão por que o pensamento se dá sobretudo através de nosso sangue; pois neste os elementos das partes encontram-se mais bem misturados" (como citado em Barnes, 2003, p. 223). Assim, é compreensível sua perspectiva de um coração como sede do intelecto, devido ao acúmulo de sangue nesta região.

\section{O Cérebro como Centro da Razão}

A estreita relação existente entre a filosofia e a arte da medicina possibilitou diversas especulações sobre a relação entre a mente e o corpo na Grécia Antiga. Frias (2001, 2004) traz luz ao assunto, enfatizando tanto as influências que a filosofia teria sofrido da medicina grega, quanto às oriundas da filosofia - sobretudo a pré-socrática -, na participação da "construção" do pensamento médico. Numa minuciosa avaliação da relação entre o conhecimento médico estabelecido pelo Corpus Hippocraticum e o pensamento filosófico, Frias (2001) considera que Platão se utilizou dos modelos da medicina hipocrática no desenvolvimento de certas idéias filosóficas como, por exemplo, sua explicação para os estados caracterizados por Platão como mania e sua discussão sobre as doenças da alma. Ao mesmo tempo, Frias (2004) também aponta que são as doutrinas médico-filosóficas elaboradas o que une os filósofos pré-socráticos a Hipócrates. Por este motivo, encontram-se presentes na obra hipocrática as formas de pensar, próprias do homem grego da época antiga, referentes àquilo que apresentam os filósofos présocráticos.

Mas apesar de todas as discussões feitas pelos filósofos pré-socráticos, o primeiro a apontar o cérebro como sede da razão e centro de todas as sensações foi Alcmeon de Crotona, filósofo e médico, que viveu por volta de 500 - 450 a.C. (Codellas, 1932; Crivellato \& Ribatti, 2007; Doty, 2007; Finger, 2000; Frias, 2004; Gross, 1995, 1998a; Huffman, 2008). Suas propostas tiveram grande influência sobre o Corpus hippocraticum e, indiretamente, sobre a obra de Platão (Frias, 2004; Huffman, 2008). 
Segundo Doty (2007), a proposta feita por Alcmeon de que a mente humana seria criada pelo cérebro é comparável a uma revolução no conhecimento humano, tanto quanto às propostas de Copérnico e Darwin.

Segundo Teofrasto, em Sobre os Sentidos, Alcmeon considerou o cérebro como sede da sensação e da cognição (Barnes, 2003; Codellas, 1932; Kirk et al., 1990). Além disso, foi o primeiro a definir as diferenças entre os animais e os seres humanos, afirmando que estes seriam os únicos capazes de compreender, enquanto os animais poderiam apenas perceber. Diferente de Empédocles, Alcmeon supôs compreensão e percepção como processos distintos (Barnes, 2003; Codellas, 1932; Kirk et al., 1990).

Ainda, Alcmeon discutiu os sentidos, propondo a existência de canais sensoriais (poroi) os quais levariam as sensações até o cérebro. Como conta Teofrasto, "todos os sentidos estão, de alguma forma, ligados ao cérebro. Por esse motivo, tornam-se incapacitados se o cérebro for movido ou tirado de posição; porque tal obstrui as passagens através das quais operam os sentidos" (como citado por Barnes, 2003, p. 108). Alcmeon ainda apontou a existência de dois poroi os quais conectariam os olhos ao cérebro - alguns autores consideram aqui tratar-se, sem dúvidas, dos nervos ópticos (Crivellato \& Ribatti, 2007; Doty, 2007; Gross, 1998a). Entretanto, há certa discordância e ausência de evidências de que Alcmeon realmente realizou uma dissecação com fins exploratórios e que realmente fez tais observações (Batista, 2003; Crivellato \& Ribatti, 2007; Doty, 2007; Frias, 2004; Gross, 1998a; Huffman, 2008).

Outro aspecto importante do trabalho de Alcmeon é sua proposta da primeira doutrina médica ocidental sobre a relação entre saúde e doença (Frias, 2004). Provavelmente influenciado pelos pitagóricos, Alcmeon de Crotona apontou pares de potências opostas (dýnamis) - úmido e seco, frio e quente, amargo e doce. Quando misturados de forma equilibrada (isonomia) no interior do corpo humano, estes pares proporcionariam ao sujeito o estado de saúde; da mesma forma, a perda desse equilíbrio entre as dýnamis seria responsável pelo estado de enfermidade (Codellas, 1932; Doty, 2007; Frias, 2004; Huffman, 2008).

Outros filósofos pré-socráticos também adotaram e expandiram as propostas de Alcmeon. Anaxágoras de Clazómena (500 - 428 a.C.) e Diógenes de Apolônia (citado na seção anterior) reconheceram que, assim como apontado por Alcmeon, todas as sensações estão conectadas ao cérebro. Entretanto, é com o médico Hipócrates de Cós (aproximadamente 460 a.C.) que a proposta de Alcmeon ganha força e divulgação.

\section{A Medicina e o Corpus hippocraticum}

Segundo Batista (2003), a medicina grega se estabelece por volta do século $\mathrm{V}$ a.C., sendo possível graças à nova perspectiva adotada pela escola lidera por Hipócrates. Visto como um dos autores mais misteriosos de toda a medicina, considera-se que Hipócrates nasceu por volta do ano de 460 a. C., na cidade de Cós, localizada em uma pequena ilha na costa dórica - atual Turquia. A ilha de Cós era conhecida por abrigar uma das grandes escolas médicas da época e especula-se sobre a existência de uma rivalidade entre as escolas de Cós (considerada mais voltada para o prognóstico) e a escola médica localizada na ilha de Cnido (considerada mais voltada para o diagnóstico). Entretanto, há certa divergência sobre a real existência desta rivalidade (Batista, 2003; Finger, 2000; Frias, 2004; Gross, 1998a; Hipócrates, trad. 2002).

Apontado como o pai da medicina e conseqüentemente um dos principais médicos da Antiguidade, atribui-se a Hipócrates a autoria da chamada Corpus hippocraticum ou "Coleção Hipocrática". Esse conjunto de textos médicos, na verdade, reúne cerca de sessenta tratados médicos, cuja maior parte foi aparentemente redigida entre os anos 450 e 300 a.C. Devido apenas a esse fato, entendese que todas as obras não puderam ser redigidas por um só indivíduo. Seu conteúdo varia amplamente nos temas abordados, discorrendo sobre embriologia, fisiologia, patologia geral e ginecologia, por exemplo. Além disso, muitas vezes os autores desses inúmeros livros divergem em inúmeros pontos (Finger, 1994, 2000; Frias, 2004; Gross, 1998a; Hipócrates, trad. 2002).

No Corpus hippocraticum, o cérebro é apontado como a sede do julgamento, das emoções e de todas as atividades do intelecto, assim como a causa dos transtornos neurológicos, tais como espasmos, convulsões e desordem da inteligência (Hipócrates, trad. 2002; Panourias, Skiadas, Sakas, \& Marketos, 2005). No Tratado Dos Ferimentos da Cabeça, numerosas referências a distúrbios de movimento são feitas, incluindo vários tipos de paralisias (Hipócrates, trad. 2002, Panourias et al., 2005). Ainda nesse tratado, há referências a distúrbios na fala, além da recomendação do uso de trepanação no tratamento de lesões cranianas (Finger, 2000; Hipócrates, trad. 2002; Panourias et al., 2005).

No tratado Da Natureza do Homem, encontra-se a doutrina humoral. Esta doutrina serviu como base para toda prática médica ocidental por quase dois milênios (Batista, 2003; Finger, 2000; Frias, 2004; Hipócrates, trad. 2002). Basicamente, propõe que o corpo é composto por quatro humores: sangue, flegma, bile amarela e bile negra. A saúde estaria associada com a perfeita justa proporção destes humores, tanto qualitativa quanto quantitativamente. A doença seria resultado do isolamento de um dos humores em alguma região do corpo, desequilibrando seu funcionamento. Este princípio é muito próximo daquele proposto por Alcmeon sobre os estados de saúde e enfermidade.

Ao mesmo tempo, esse equilíbrio entre os quatro $h u$ mores nos remete diretamente à interação dos quatro elementos primordiais apresentados no pensamento de Empédocles de Agrigento. Essa explicação também é utilizada por Platão, no Timeu, conforme apontado por 
Galeno (Batista, 2003). Ao mesmo tempo, a mesma relação entre saúde e harmonia dos elementos componentes pode ser encontrada em Alcmeon de Crotona, como citado antes. Vemos aqui uma convergência de diversas propostas feitas pelos filósofos pré-socráticos. Como marca Batista (2003), em um dado momento, tanto a filosofia pré-socrática quanto a medicina grega clássica convergiram para um ponto em comum, bem representado pelo tratado Da Natureza do Homem.

Ainda, cada um dos humores estaria associado a um dos quatro elementos primordiais (água, terra, fogo e $a r$ ) e a um órgão interno específico. Assim, o sangue estaria associado ao ar e ao coração; a bile negra, à terra e ao baço; a bile amarela, ao fogo e ao fígado; e a flegma, à água e ao cérebro. Esta relação está representada na Tabela 1.

Tabela 1

Associação entre Cada Um dos Humores, Elementos e Órgãos, Segundo a Medicina Hipocrática

\begin{tabular}{lll}
\hline Humores & Elementos & Órgãos \\
\hline Bile Amarela & Fogo & Fígado \\
Bile Negra & Terra & Baço \\
Flegma & Água & Cérebro \\
Sangue & Ar & Coração \\
\hline
\end{tabular}

A insanidade mental estaria associada a uma alteração do cérebro. Essa alteração cerebral seria provocada por uma modificação das concentrações de flegma no organismo. Em Da Sagrada Doença, um dos mais famosos tratados do Corpus hippocraticum, seu autor logo no início propõe que a epilepsia - conhecida como "doença sagrada" - não possui nenhum caráter divino "nem de mais sagrado do que as outras, mas a natureza e a origem são as mesmas das outras doenças" (Hipócrates, trad. 2002, p. 112). Assim, considera que "o cérebro é a origem dessa afecção", pois ao ocorrer influxos de ar para o cérebro, haveria o aparecimento de convulsões, perda da voz e dos sentidos (Hipócrates, trad. 2002, p. 112).

Curiosamente, em todo o Corpus hippocraticum não há evidências de que autopsias humanas foram realizadas. Hipócrates teria vivido em uma época na qual autopsias não eram realizadas por questões religiosas (Finger, 2000). Provavelmente seus aprendizados sobre anatomia e fisiologia se deram através de observações de soldados e outros ferimentos os quais permitiram uma maior observação do corpo humano (Finger, 2000; Gross, 1998a).

\section{A Alma de Platão e o Coração de Aristóteles}

Apesar da grande influência dos tratados reunidos sob o nome de Hipócrates, a questão de qual órgão - cérebro ou coração - seria o centro do intelecto permaneceu em aberto por toda a Grécia Antiga. Nesta discussão, estiveram de um lado aqueles favoráveis a Hipócrates e adep- tos à tese cefalocentrista - ou seja, de um cérebro como sede das diversas funções mentais, como Diógenes - e, do outro lado, aqueles adeptos à uma visão cardiocentrista - ou seja, de o coração como a sede do intelecto, como Empédocles. Entretanto, duas figuras importantes da filosofia grega antiga são geralmente apresentadas como emblemáticas nessa discussão: Platão (427 - 347 a.C.) e Aristóteles (384 - 322 a.C.).

Em sua obra Timeu, Platão considera que a alma seria composta por três partes. Sua parte mais divina e imortal, vinda da própria alma do universo, teria o cérebro como sede e controlaria todo o resto do corpo. Esta parte imortal da alma seria o intelecto $(\log o s)$. A cabeça, tal como uma "cidadela", abrigaria a parte imortal da alma e se ligaria ao restante do corpo por um "istmo", o pescoço, mantendo separadas, mas ainda em contato, tanto a alma divina e imortal quanto a alma mortal, localizada no tronco. Esta alma mortal seria subdividida em duas outras: a primeira se encontraria na porção torácica, situada especificamente no coração - sede da coragem e dos sentimentos. Funcionaria como um "posto de guarda". A outra parte da alma mortal estaria na região abdominal, entre o diafragma e o umbigo, perto do fígado e seria a sede dos desejos. Estas duas últimas estariam separadas pelo diafragma - músculo divisor do tronco em dois segmentos. Para aplacar os efeitos da cólera decorrente da ação do fogo sobre o coração, os deuses criaram os pulmões. De estrutura similar a uma esponja a qual permite a entrada de ar e de líquidos, os pulmões possibilitariam o resfriamento do coração (Frias, 2001, 2004).

Platão demonstrou em sua obra possuir conhecimento das obras hipocráticas. Como bem analisa Frias (2001), Platão adotou o modelo da medicina para o desenvolvimento de certas idéias filosóficas. O Timeu de Platão é considerado como a obra responsável por levar até a Idade Média as principais idéias pré-socráticas e hipocráticas referentes ao cérebro, ao corpo e, de forma geral, ao universo (Finger, 2000). Ao tomar posição claramente cefalocentrista, Platão favoreceu a divulgação de tal visão com seu prestígio.

Entretanto, Aristóteles via outra função para o cérebro. Claramente cardiocentrista, considerava o coração como sede da "alma", das emoções e do intelecto. Na verdade, pode-se dizer que foi Aristóteles quem deu um caráter mais formal a esta posição. Filósofo e também estudioso de biologia, Aristóteles é geralmente considerado pai da anatomia comparada, assim como o primeiro embriologista e taxonomista (Crivellato \& Ribatti, 2007; Gross, 1995).

No Tratado Da Alma, Aristóteles (trad. 2001) propôs que os seres animados se diferenciam dos seres inanimados, pois possuiriam um princípio que lhes dá a vida: a alma. Além disso, distinguiu diferentes faculdades desta alma: a faculdade vegetativa, a sensitiva e a intelectual. Segundo Aristóteles, os vegetais teriam apenas a alma vegetativa, o princípio mais básico e elementar da vida, responsável pelas funções biológicas como nutrição, cres- 
cimento e geração. Os animais irracionais capazes de movimento seriam dotados da alma sensitiva, responsável pelas sensações e pelo movimento do corpo (Aristóteles, trad. 2001). Ao discutir sobre a alma sensitiva no tratado Da Alma, Aristóteles faz uma exposição de cada um dos cinco sentidos.

Para Aristóteles, o ser humano se diferenciaria dos animais por ser o único a possuir a faculdade intelectual. Somente o ser humano teria a capacidade e o desejo de conhecer (French, 1978). Aristóteles caracterizou o Intelecto como "aquela parte da alma que permite conhecer e pensar" (Aristóteles, trad. 2001, p. 100). O Intelecto teria a "capacidade de receber a forma, ou algo enquanto forma" (Aristóteles, trad. 2001, p. 101). O objeto, atingido pelos sentidos, seria também atingido pela inteligência, a qual abstrairia nele a noção de ser. Assim, o ser humano seria o único ser vivo dotado das três faculdades da alma: a vegetativa, a sensitiva e a intelectual.

Todas as faculdades da alma residiriam no coração. Para ele, o coração possuiria papel importante por se encontrar numa posição central do corpo, além de ser responsável pela produção de calor do corpo, fundamental para a vida. Indo além, considerou o coração como a fonte do sangue e a origem dos vasos sanguíneos (French, 1978). Ainda, Aristóteles observou que o coração é o órgão a se desenvolver primeiro no embrião (Crivellato \& Ribatti, 2007; Gross, 1995).

Segundo Aristóteles, o cérebro seria essencial para o funcionamento do organismo, associado com o coração. Ambos formariam uma unidade a qual permitiria o funcionamento normal do corpo (Gross, 1995, 1998a). Naturalmente quente, o coração precisaria ser contrabalançado, com o objetivo de se manter correto e justo. O cérebro, naturalmente frio, teria a função de regular o calor produzido pelo coração no sangue. Ao alcançar o cérebro logo após saírem do coração, o sangue aquecido provocaria a evaporação da água presente no cérebro, resfriando-se (Crivellato \& Ribatti, 2007; Gross, 1995). Ao esfriar o calor do coração, ocorreria a produção de flegma no cérebro (Gross, 1995).

Assim, por ser úmido e frio, o cérebro não poderia ser a sede da alma, tendo este o papel repassado para o coração. Aristóteles fez diversas observações anatômicas, fisiológicas, comparativas e embriológicas como suporte para sua posição cardiocentrista (Gross, 1995). Além disso, comparou coração e cérebro e apresentou alguns argumentos para considerar o coração, e não o cérebro, a sede do intelecto e das sensações. A Tabela 2 apresenta um quadro comparativo dos argumentos apresentados por Aristóteles (Gross, 1995).

Tabela 2

Argumentos de Aristóteles para o Coração como Centro das Sensações e Movimento, em vez do Cérebro. Adaptado de Gross (1998a)

Coração Cérebro

\section{Afetado pelas emoções}

Todos os animais possuem um coração ou um órgão similar

Fonte do sangue, necessário para a sensação

Quente, característica de alta vitalidade

Ligado a todos os órgãos sensoriais e músculos, através dos vasos sanguíneos

Essencial para a vida

Primeiro formado e o último a parar

Sensível

Encontra-se em posição central, ideal para o controle central

\section{Não afetado}

Somente vertebrados e cefalópodes possuem um, e só alguns tem sensações

Sem sangue e, portanto, sem sensações

Frio

Sem ligação aos órgãos ou a ligação é irrelevante

Nem tanto

Segundo a ser formado

Insensível: se o cérebro de um animal vivo ficar descoberto, ele pode ser cortado sem que haja sinal de dor ou desconforto

Nem tanto
Apesar disso, Aristóteles fez interessantes considerações anatômicas sobre o cérebro. Observou duas membranas (as meninges) que envolveriam o cérebro: uma externa, situada próxima ao crânio - sem dúvidas a dura mater; e outra interna, envolvendo o próprio cérebro, mais delicada - provavelmente a pia mater ou a pia mater e a aracnóide (Crivellato \& Ribatti, 2007; French, 1978; Gross, 1995).

Além disso, observou que o cérebro era frio, com pouco sangue e bipartido. Distinguiu entre o cérebro (enkephalos) e o cerebelo (parenkephalis). Ainda, reconheceu um pequeno furo no interior do cérebro, prova- 
velmente o sistema ventricular, além de fazer referências a um fluído no interior do encéfalo, provavelmente o líquido cefalorraquidiano (Crivellato \& Ribatti, 2007; Gross, 1995). Aristóteles ainda observou que o ser humano possui maior cérebro em relação a seu tamanho e argumentou que este fato aconteceria pois o coração humano era o mais quente e o mais rico, devido a seu intelecto superior (Crivellato \& Ribatti, 2007; French, 1978; Gross, 1995). Assim, um cérebro maior permitiria um melhor resfriamento, possibilitando uma atividade mental normal (Gross, 1995).

Apesar dos argumentos e das supostas evidências de Aristóteles para a tese cardiocentrista, foi a posição cefalocentrista dos médicos Alcmeon e Hipócrates que prevaleceu. Tal posição foi transmitida ao mundo árabe e para a Europa medieval e renascentista através do Timeu de Platão (Gross, 1995). Entretanto, a posição cardiocentrista de Aristóteles não desapareceu por completo. Gross (1998a) aponta a existência da combinação de ambas visões e cita o exemplo do médico árabe da Idade Média, Ibn Sina (conhecido como Avicena). Este considerou que as sensações, a cognição e o movimento se localizariam no cérebro, mas que este seria controlado pelo coração.

Apesar do mau entendimento do funcionamento cerebral, Aristóteles possuiu papel essencial na facilitação subseqüente do estudo do cérebro. No geral, é a importância dada por Aristóteles à dissecação, associada com seu prestígio, que incentivará outros estudiosos a desenvolver estudos anatômicos (Gross, 1998a).

\section{A Escola de Alexandria}

Na Alexandria Ptolomaica, durante o século III a.C., surgiu uma renomada escola de medicina, onde dois grandes médicos se destacaram: Herófilo (335 - 280 a.C.) e Erasístrato (310 - 250 a.C.). Entretanto, seus trabalhos são conhecidos através de citações feitas por Galeno (130 - 201 d.C.), bastante influenciado por esses dois autores (Crivellato \& Ribatti, 2007; Finger, 2000; Gross, 1998a; Vrettos, 2005).

Nascido na Calcedônia no final do século IV a.C., Herófilo é conhecido por sua série de descrições minuciosas sobre diversas estruturas anatômicas do corpo humano. Fez descrições precisas do cérebro, examinou as diferenças entre tendões e nervos - sendo o primeiro a diferenciá-los - e estudou extensamente o olho (Crivellato \& Ribatti, 2007; Finger, 2000). Descreveu pelo menos sete pares dos nervos cranianos: o óptico, o motor ocular, o trigêmeo, o motor ocular externo, o facial, o auditivo, e o nervo hipoglosso (Crivellato \& Ribatti, 2007; Vrettos, 2005).

Além disso, distinguiu os ventrículos cerebrais: os ventrículos laterais, o terceiro e o quarto ventrículo; contabilizando os ventrículos laterais como apenas um e apresentando, assim, três ventrículos no total. Considerou que os ventrículos armazenavam e permitiam a passagem da pneuma psíquica do cérebro para os nervos. A pneuma psíquica, como é explicada em Erasístrato mais à frente, seria aquilo que possibilitaria o movimento, as sensações e os pensamentos no sujeito (Vrettos, 2005).

Além disso, chamou a atenção para o quarto ventrículo onde, em sua opinião, se alojaria a alma e forneceu uma descrição precisa das meninges. Também fez considerações a respeito do sistema vascular por observação direta, diferenciando entre artérias, veias e vasos capilares. Ainda, foi responsável pelo uso do relógio de água para medições precisas da pulsação (Finger, 2000; Gross, 1998a; Vrettos, 2005).

Por seus estudos, Herófilo concluiu que o corpo seria governado por quatro forças: o calor no coração, a percepção nos nervos, a nutrição no fígado e o pensamento no cérebro. Como a maior parte dos médicos de sua época, Herófilo foi influenciado por Hipócrates. Há citações freqüentes de seu trabalho principal Sobre Dissecações (Finger, 2000; Gross, 1998a; Vrettos, 2005).

Erasístrato foi sucessor de Herófilo no comando da escola de Alexandria e é considerado como o fundador da fisiologia. Acreditava que as artérias eram preenchidas de ar e concluiu que todos os órgãos eram conectados pelas artérias, veias e nervos. Assim como Herófilo, também diferenciou os nervos motores e os sensitivos (Vrettos, 2005). Além disso, Erasístrato apontou que o número de circunvoluções estaria em relação direta com o grau de evolução intelectual (Crivellato \& Ribatti, 2007; Finger, 2000; Gross, 1998a; Vrettos, 2005).

Para Erasístrato, seria a pneuma ou espíritos - geralmente traduzido como "sopro da vida" e composta de sutis partes da matéria ou átomos invisíveis aos olhos presente no ar-que desempenha o grande papel na fisiologia. Este autor distingue entre a pneuma vital e a pneuma psíqui$c a$, as quais se localizariam respectivamente no ventrículo esquerdo do coração e nos ventrículos do cérebro.

$\mathrm{O}$ ar que entra nos pulmões durante a respiração seria levado até o coração pelas artérias e lá misturado com o sangue, sendo convertido em pneuma vital. Estas minúsculas partículas seriam transportadas pelo sangue para todo o corpo através da rede arterial. No cérebro, a pneuma vital seria transformada em pneuma psíquica, que seria, por sua vez, direcionada as diversas partes do corpo pelo sistema nervoso. Seria esta pneuma psíquica a responsável pela contração muscular, as sensações e a formação dos pensamentos. Assim, enquanto o sangue nutriria os tecidos e os órgãos, seria a pneuma que os animaria (Crivellato \& Ribatti, 2007; Gross, 1998a; Vrettos, 2005).

Esse sistema apresentado por Erasístrato se constitui como uma espécie de síntese entre a teoria da pneuma apreciada pelos médicos da escola dogmática como Praxágoras - e o naturalismo atomístico de Demócrito (Solmsen, 1950). Aqui, não há forças ocultas em ação. Ao mesmo tempo, Erasístrato não considerava os quatro elementos importantes nesse sistema. Ele discordou da teoria humoral e considerou que a maioria das enfermidades ocorreriam por acúmulo em alguma determinada região do corpo de substâncias alimentares mal digeridas. 
Segundo Vrettos (2005), tanto Herófilo quanto Erasístrato praticaram vivissecção de seres humanos, geralmente criminosos. Com a permissão das autoridades locais, ambos dissecavam os sujeitos vivos e observavam (enquanto ainda respiravam) todas as partes do corpo.

Grande parte da obra desses dois autores é conhecida a partir dos depoimentos de Galeno. Ao lado de Hipócrates, Cláudio Galeno é considerado um dos mais famosos médicos do mundo antigo. Nascido em Pérgamo, uma província romana no oeste da Ásia Menor, Galeno viveu no século II d.C., quase seis séculos depois do pai da medicina, e sua contribuição foi extremamente relevante para a área da medicina, principalmente para a anatomia e fisiologia. Seus ensinamentos perduraram por mais de treze séculos e serviram como guia na prática científica e médica durante a Idade Média (Crivellato \& Ribatti, 2007; Finger, 1994; Gross, 1998a).

Galeno executou experiências e provou empiricamente que Erasístrato estava errado, mostrando que nas artérias também corriam sangue - e não ar como tinha considerado Erasístrato (Gross, 1998b; Vrettos, 2005). Fez pesquisas no sistema nervoso e reconheceu os nervos recorrentes, os raquidianos e os cervicais, os gânglios nervosos e uma parte do sistema simpático (Crivellato \& Ribatti, 2007; Gross, 1998a, 1998b). Além disso, Galeno associou a imaginação, a inteligência e a memória com a substância cerebral, atribuindo ao cérebro o papel de sede de todas as faculdades cognitivas (Crivellato \& Ribatti, 2007; Finger, 2000; Gross, 1998a).

Como um grande admirador do trabalho de Platão (428 - 347 a.C.), Galeno considerou que as três faculdades da mente (ou alma) seriam divididas em três partes, assim como aponta Platão: os espiritos animais, originados no cérebro; os espiritos vitais, originados no coração; e os espíritos naturais, originados no fígado. Para Galeno, os espíritos vitais, produzidos no ventrículo esquerdo do coração, eram carregados até a base do cérebro, onde se tornavam espíritos animais. Os espíritos animais eram armazenados nos ventrículos até serem necessários, sendo levados através dos nervos para os músculos ou para mediar sensações. Pode-se perceber que o sistema circulatório apresentado possui grande influência de Erasístrato (Crivellato \& Ribatti, 2007; Finger, 1994, 2000; Gross, 1998a, 1998b; Vrettos, 2005).

Além disso, Galeno revitalizou a Teoria Humoral de Hipócrates e ressaltou a importância dos quatro temperamentos, conforme o predomínio de um dos quatro $h u$ mores: sangüíneo, fleumático, colérico (de cholé, bile) melancólico (de melános, negro + cholé, bile). Considerou, desse modo, o comportamento das pessoas a partir do equilíbrio e harmonia dos humores constituintes do ser humano (Finger, 2000; Gross, 1998b).

Utilizando os trabalhos de diversos autores, como Herófilo, Erasístrato, Hipócrates e Platão (apenas para citar alguns), Galeno reorganizou o conhecimento de sua época acerca da relação entre as funções mentais e o cé- rebro. Com Galeno, o conhecimento sobre o sistema nervoso recebeu grande impulso teórico. Após a sua morte no século II, observa-se um longo eclipse no que diz respeito ao estudo prático do cérebro humano, marcando o pensamento ocidental até o século XVI. Sua contribuição ao estudo da relação entre mente e cérebro foi profunda, sendo personagem fundamental na divulgação da idéia do cérebro como sede da alma, além de uma inédita descrição do sistema nervoso (Finger, 2000; Gross, 1998b).

O valor atribuído por Galeno aos espíritos animais, como responsáveis pela animação do corpo, perdurou por séculos na compreensão do funcionamento nervoso e isto se refletiu nos estudos de René Descartes, por exemplo. No século XVII, quando Descartes apresentou suas idéias, os espiritos animais ainda eram considerados como responsáveis pelas funções mentais. De certa forma, Descartes apresentou uma visão mecânica fluída do cérebro, similar àquela apresentada por Galeno, utilizando muitos de seus conceitos como partida em sua explicação sobre a interação da alma e do cérebro.

De fato, a idéia de espíritos animais responsáveis pela animação do corpo só será abandonada no final do século XVIII, com os estudos de Luigi Galvani e Alessandro Volta sobre a bioeletricidade.O trabalho de Galeno vai influenciar por séculos e servir de base do pensamento medieval científico nos estudos em fisiologia e anatomia, assim como a visão acerca do cérebro e sua relação com a alma - ou mente (Gross, 1998b). Entretanto, fica nítido que sua contribuição está diretamente associada das contribuições anteriores.

\section{Considerações Finais}

Desde as civilizações mais antigas, percebe-se uma preocupação em responder questões fundamentais acerca da natureza da mente humana. A procura por tais respostas, ainda em um período remoto, provocou uma produção de conhecimento com fortes características míticoreligiosas (Castro \& Landeira-Fernandez, 2010; Gomes, 2004). Como aqui apontado, é na antiga civilização grega que ocorre um primeiro momento de mudança de um pensamento mítico-religioso para um pensamento mais próximo daquele familiar ao sujeito moderno. De fato, é com o surgimento do pensamento filosófico grego que se formam as bases do pensamento ocidental. Provavelmente por isso, é possível observar um paralelo entre o pensamento filosófico grego e desenvolvimento atual de diversos campos de saber.

Reunidas em torno da neurociência, as áreas relacionadas ao estudo do cérebro e da mente têm gerado grande expectativa em relação ao entendimento final da natureza do cérebro humano. Ao pensarmos sobre um desenvolvimento atual desse campo, nos vemos ainda hoje guiados pelas mesmas questões que incentivaram os pen- 
sadores antigos. Por isso, não é absurdo dizer que muitos dos conceitos atuais da neurociência moderna encontram suas origens nas especulações dos antigos pensadores gregos (Crivellato \& Ribatti, 2007). Neles, vemos surgir observações mais sistemáticas sobre a estrutura e o funcionamento do corpo - especificamente do cérebro, da mente e a relação entre estas duas entidades.

Nos tempos homéricos, o grego antigo não apresentava uma visão de corpo e mente bem definido. Isto ocorre somente quando surge uma forma de pensar própria da civilização grega, possibilitando a formação das bases do pensamento ocidental. Essa filosofia nascente permitiu o desenvolvimento de diversos questionamentos a respeito das diversas atividades mentais, além da elaboração de diferentes especulações sobre o funcio- namento das estruturas corporais e sobre a relação a alma (mente) e o corpo.

E assim como nos atuais estudos da neurociência moderna, podemos perceber duas grandes preocupações no pensamento antigo grego: (a) uma busca pela localização do centro das funções mentais, representada aqui pela "disputa" entre as teorias cardiocentristas e cefalocentristas; e (b) um conjunto de especulações que procura responder a relação entre o centro coordenador localizado no corpo (seja o coração, seja o cérebro) e a alma (ou mente), representado aqui pelo surgimento da teoria dos humores de Hipócrates e sua contínua reformulação até a teoria dos temperamentos de Galeno. Os principais eventos citados nesse estudo são apresentados na linha do tempo representada na Figura 1.

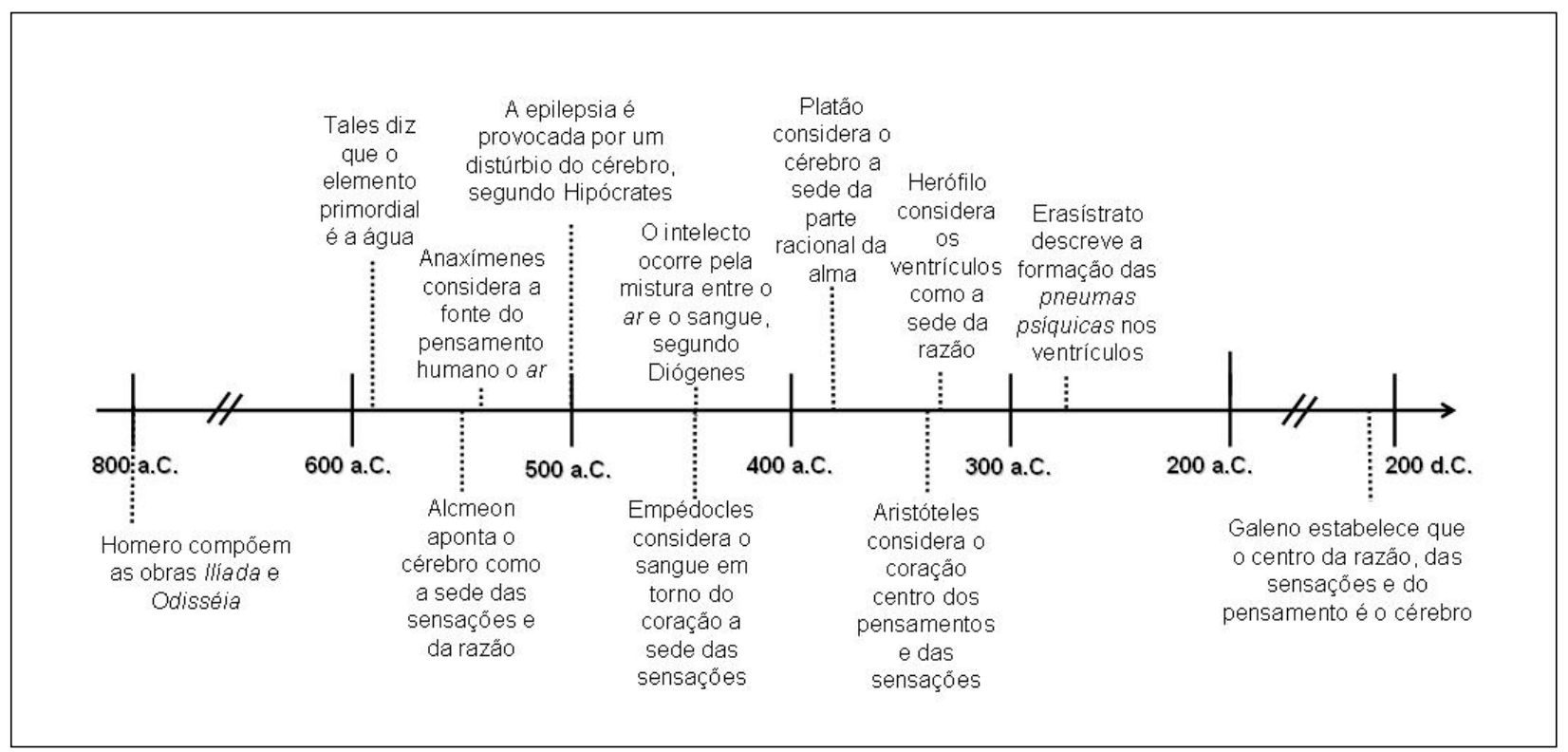

Figura 1. Linha do tempo dos principais eventos citados.

A partir dessas questões, dois conjuntos de contribuições dos antigos pensadores gregos se encontram ainda presentes na atual neurociência. Primeiro, o reconhecimento do cérebro como sede da razão por Alcmeon de Crotona (e a conseqüente divulgação por Hipócrates desta posição), guiando por definitivo os passos dos futuros pensadores em suas observações. Além disso, as contribuições de Herófilo e Erasístrato nas técnicas de investigação e no conhecimento neuroanatômico (e sua conseqüente melhoria por Galeno), permitindo o desenvolvimento do campo de investigação.

Vale também ressaltar a importância do trabalho de Galeno e seu impacto. Suas obras vão influenciar por séculos e servir de base para o pensamento medieval científico nos estudos de fisiologia e anatomia, além de seu papel fundamental na visão sobre a relação entre o cérebro e a alma (ou mente). O valor atribuído aos espíritos animais como responsáveis pela animação do corpo vai perdurar por séculos na compreensão do funcionamento do sistema nervoso. Isto irá se refletir nos estudos de René Descartes (1596 - 1650), por exemplo. No século XVII, quando Descartes apresenta suas idéias, os espíritos animais ainda eram considerados como responsáveis pelas funções mentais. É a liberação dos espíritos animais, armazenados na glândula pineal, a causa dos movimentos no organismo, por exemplo.

De fato, a idéia de espíritos animais responsáveis pela animação do corpo só será abandonada no final do século XVIII, com os estudos de Luigi Galvani e Alessandro Volta sobre a bioeletricidade (Finger, 1994; Gross, 1998a). Entretanto, podemos traçar um paralelo interessante entre esses antigos espíritos animais e os modernos neurotransmissores e impulsos elétricos os quais habitam e possibilitam o funcionamento do sistema nervoso - assim como os antigos espíritos animais. Apesar de paradigmas bem distintos, ambos os conceitos refletem 
uma tentativa racional de responder como comandos mentais saem dos centros de controle e percorrem o corpo.

Outro paralelo interessante que podemos traçar é a proposta de Platão para a divisão da alma. Ao sugerir a existência de uma alma tripartida, Platão aponta regiões distintas para diferentes características do sujeito: o intelecto, no cérebro; as emoções, no coração; e os desejos mais básicos (como sexuais e/ou nutritivos), no fígado. Assim como os frenologistas do século XIX e, em certo nível, como os atuais neurocientistas, Platão procura associar distintas funções mentais com diferentes estruturas corporais. Da mesma forma que o exemplo de Galeno, ambas as premissas partem de paradigmas bem distintos, mas apontam para uma mesma preocupação: localizar as diversas regiões responsáveis pelas funções mentais do sujeito.

Tal paralelo entre a perspectiva de Platão e das três partes da alma e a tentativa de localizar nas diferentes regiões do cérebro as diversas funções mentais, ganha um exemplo curioso com a proposta do "cérebro triúnico" do neurocientista Paul MacLean. Segundo este, o cérebro humano seria especialmente dividido em três partes: o chamado "cérebro reptiliano", associado com a necessidade de sobrevivência; o sistema límbico, associado com as emoções mais básicas; e o neocórtex, associado com as funções do intelecto e da razão. Apesar de nenhuma ligação aparente, ambas as propostas - tanto a de Platão quanto a de MacLean - apresentam uma organização e hierarquia similar.

Ao fazermos esse breve olhar sobre as contribuições dos antigos pensadores gregos à neurociência, ficam nítidos os diversos paralelos existentes entre o desenvolvimento de diferentes campos de saber, como a neurologia, biologia, medicina, psicologia, juntamente com questões clássicas da filosofia, como a natureza da alma (ou da mente) e a origem do conhecimento. De fato, ao tentarmos traçar uma história do surgimento da neurociência, também estamos traçando uma "história natural da alma".

O presente trabalho consistiu em uma narrativa ampla de diferentes fontes relacionadas aos diversos temas abordados pela literatura, desde aspectos específicos de determinadas áreas até aspectos gerais sobre a civilização grega. Esse tipo de abordagem marca uma limitação do estudo devido ao pouco aprofundamento das fontes de informação. Devido à complexidade do pensamento grego e à abrangência das atuações dos diversos antigos pensadores gregos, cabe ressaltar que a exposição aqui pode não conseguir abranger todo o assunto. Entretanto, a temática discutida é fundamentalmente relevante, devido à inegável carência de uma organização formal sobre o assunto aqui abordado, além de marcar uma trajetória histórica do desenvolvimento de tais temas que remonta até a civilização grega.

Dessa forma, a interdisciplinaridade que se apresenta sobre o assunto desafia àquele que tenta fazer uma história do campo. Uma aproximação a partir de uma perspectiva somente da história da medicina, ou somente de uma perspectiva da história da psicologia, ou somente da filosofia, fará com que o investigador provavelmente perca algum ponto importante que caracterize o campo ou que caracterizou no passado. De certa forma, essa também pode ser uma das limitações do presente estudo.

Entretanto, nosso objetivo foi apenas apresentar as principais idéias a respeito de uma centralização da mente em seu corpo, presentes já na Grécia Antiga. Com isto, pretendemos colaborar com somente uma das muitas peças desse enorme quebra-cabeça de subsídios históricos acerca do debate mente-corpo, que revela também uma tentativa de traçar uma história da nossa própria existência.

\section{Referências}

Barnes, J. (2003). Filósofos pré-socráticos (2. ed). São Paulo, SP: Martins Fontes.

Batista, R. S. (2003). Mito, Filosofia e Medicina na Grécia Antiga: Relações entre a poesia épica, a Filosofia présocrática e a Medicina de Hipócrates. Dissertação de Mestrado não-publicada, Departamento de Filosofia, Pontifícia Universidade Católica do Rio de Janeiro, RJ.

Burnet, J. (1994). O despertar da filosofia grega. São Paulo, SP: Siciliano.

Castro, F. S., \& Landeira-Fernandez, J. (2010). Alma, mente e cérebro na Pré-história e nas primeiras civilizações humanas. Psicologia: Reflexão e Crítica, 23(1), 141-152.

Chauí, M. (2002). Introdução à história da Filosofia: Dos présocráticos a Aristóteles (2. ed). São Paulo, SP: Companhia das Letras.

Churchland, P. M. (2004). Matéria e consciência: Uma introdução contemporânea à filosofia da mente. São Paulo, SP: Editora da Universidade Estadual Paulista.

Churchland, P. S. (1996). Neurophilosophy: Toward a unified science of the mind-brain. Cambridge, MA: Massachusetts Institute of Technology Press.

Codellas, P. S. (1932). Alcmaeon of Croton: His life, work, and fragments. Proceedings of the Royal Society of Medicine, 25(7), 1041-1046.

Crivellato, E., \& Ribatti, D. (2007). Soul, mind, brain: Greek philosophy and the birth of neuroscience. Brain Research Bulletin, 71, 327-336.

Demetrios, J. S. (2001). Functional neuroanatomy in the PreHippocratic Era. Neurosurgey, 48(6), 1352-1357.

Doty, R. W. (2007). Alkmaion's discovery that brain creates mind: A revolution in human knowledge comparable to that of Copernicus and of Darwin. Neuroscience, 147, 561-568.

Finger, S. (1994). Origins of neuroscience: A history of explorations into brain function. New York: Oxford Press.

Finger, S. (2000). Minds behind the brain: A history of the pioneers and their discoveries. New York: Oxford Press.

French, R. K. (1978). The thorax in history 1. From ancient times to Aristotle. Thorax, 33, 10-18.

Frias, I. M. (2001). Platão, leitor de Hipócrates. Londrina, PR: Editora da Universidade Estadual de Londrina.

Frias, I. M. (2004). Doença do corpo, doença da alma: Medicina e Filosofia na Grécia clássica. Rio de Janeiro, RJ: Editora da Pontifícia Universidade Católica do Rio de Janeiro.

Gomes, W. B. (2004). Primeiras noções da psique: Das concepções animalistas às primeiras concepções hierarquizadas em antigas civilizações. Memorandum, 7, 32-46. 
Gross, C. G. (1995). Aristotle on the brain. The Neuroscientist, 1(4), 245-250.

Gross, C. G. (1998a). Brain, vision, memory: Tales in the history of neuroscience. Cambridge, MA: Bradford Book.

Gross, C. G. (1998b). Galen and the squealing pig. The Neuroscientist, 4(3), 216-221.

Huffman, C. (2008). Alcmaeon. In The Stanford Encyclopedia of Philosophy. Retrieved January 12, 2009, from http:// plato.stanford.edu/archives/win2008/entries/alcmaeon/

Ivanovic-Zuvic, F. (2004). Consideraciones epistemológicas sobre la medicina y las enfermedades mentales en la Antigua Grecia. Revista Chilena de Neuro-Psiquiatría, 42(3), 163-175.

Kirk, G. S., Raven, J. E., \& Schofield, M. (1990). The presocratic philosophers ( $\left.2^{\text {nd }} \mathrm{ed}\right)$. Cambridge, MA: Cambridge University Press.

Landeira-Fernandez, J., \& Silva, T. A. (Eds.). (2007). Intersecções entre Psicologia e Neurociências. Rio de Janeiro, RJ: MedBook.

Marcondes, D. (2008). Iniciação à história da Filosofia: Dos pré-socráticos a Wittgenstein (12. ed). Rio de Janeiro, RJ: Jorge Zahar.

Mondolfo, R. (1973). O pensamento antigo: História da Filosofia greco-romana (3. ed., Vols. 1-2). São Paulo, SP: Mestre Jou.

Panourias, I. G., Skiadas, P. K., Sakas, D. E., \& Marketos, S. G. (2005). Hippocrates: A pioneer in the treatment of head injuries. Neurosurgey, 57(1), 181-189.

Porto, M. A. T., Moreira, M. F. S., \& Simão, M. C. F. (2001). Anatomia e fisiologia na Idade Trágica dos gregos. Mneme Revista de Humanidades, 2(4) 1-15.

Quin, C. E. (1992). The centre thought to control sensory and motor activity in the early History of Medicine. Journal of the Royal Society of Medicine, 85(2), 102-105.

Reale, G. (2002). Corpo, alma e saúde: O conceito de homem de Homero a Platão. São Paulo, SP: Paulus.

Russell, B. (2002). História do pensamento ocidental: A aventura dos pré-socráticos a Wittgenstein (6. ed). Rio de Janeiro, RJ: Ediouro.

Snell, B. (2001). A cultura grega e as origens do pensamento europeu. São Paulo, SP: Perspectiva.

Solmsen, F. (1950). Tissues and the soul: Philosophical contributions to Physiology. Philosophical Review, 59, $435-$ 468.

Vernant, J. P. (1998). As origens do pensamento antigo. Rio de Janeiro, RJ: Bertrand Brasil.

Vrettos, T. (2005). Alexandria: Cidade do pensamento ocidental. São Paulo, SP: Odysseus. 